Immunochemistry. Pergamon Press 1968. Vol. 5, pp. 585-605. Printed in Great Britain

\title{
DIGESTION OF ATOPIC ALLERGENS WITH TRYPSIN a-CHYMOTRYPSIN AND PANCREATIC KALLIKREIN, AND INFLUENCE OF THE ALLERGENS UPON THE PROTEOLYTIC AND ESTEROLYTIC ACTIVITY OF THESE ENZYMES
}

\author{
L. BERRENS \\ Department of Dermatology, Section Biochemistry of the Skin, \\ University Hospital, Utrecht, The Netherlands
}

(Received 19 December 1967; in revised form 29 April 1968)

\begin{abstract}
The action of bovine trypsin, a-chymotrypsin and pancreatic kallikrein upon a number of atopic allergens has been studied by $\mathrm{pH}$-stat measurements during short-term incubation. Most atopic allergens proved chemically resistant towards these enzymes. Graphs of enzyme susceptibility vs. the ratio of extinction coefficients E305/E280, or against the per centage of available lysine, suggest that the liability of allergens to proteolysis depends on the number of 1-deoxy-2-ketoses linked to the 6 -amino groups of lysine residues in the peptide moieties. This relationship is further exemplified with results obtained with a number of welldefined synthetic model proteins incorporating different proportions of $\mathrm{N}$-conjugated sugar.

The allergens were found to be competitive inhibitors of the proteolytic activity of trypsin and chymotrypsin, but not of kallikrein. Evidence was obtained for an additional element of non-competitive inhibition in the case of trypsin. The esterolytic activity of the three enzymes proved to be unimpaired in the presence of allergens.
\end{abstract}

\section{INTRODUCTION}

The Digestrve action of proteolytic enzymes upon atopic allergens, the substances involved in the syndrome of atopy in man (asthma, hay fever, atopic dermatitis) has for a long time intrigued research workers contriving to identify the structural site(s) triggering the allergic reaction. The rationale for applying enzymes to the study of allergen structure at first seems to have lain in their usefulness for establishing the chemical nature of the allergens and-when it became clear that most allergens belong to the class of protein-carbohydrate complexes-in the possibility of locating the allergenically active site in the peptide or the carbohydrate moiety. Apart from this, a survey of the pertinent literature reveals a growing uneasiness among authors when many allergens turned out to be resistant towards the common proteases and carbohydrases, either with respect to biological activity or to integrity of structure.

Spies et al. [1] described the action of four enzymes upon their cottonseed allergen fraction CS-13-Endo, a nondialyzable, picric acid precipitable fraction from the crude allergen sample CS-1A. The allergens were found to be degraded by crystalline trypsin, chymotrypsin, pepsin and a carboxypeptidase during incubation periods for up to 3 days; trypsin, and to a lesser extent chymotrypsin, also destroyed skin-reactivity of the allergen, but the treatment with pepsin and carboxypeptidase, though causing some chemical fragmentation, led to no apparent loss of skin-reactive potency. Herbertson, Porath and Colldahl [2] treated the nondialyzable material from aqueous extracts of alder pollen with trypsin, chymotrypsin and pepsin for $6 \mathrm{hr}$ and found no reduction of skin-reactivity. Augustin [3] reported complete destruction of crude and purified allergens from cocksfoot and timothy pollens after interaction with trypsin, 
chymotrypsin and a mould protease for $24 \mathrm{hr}$. Johnson and Marsh [4] demonstrated chemical instability of the purified allergens I-B and I-C from rye grass pollen towards digestion by trypsin, chymotrypsin and pepsin; the total digests in all cases were completely non-allergenic. Malley and Dobson [5] recently reported their purified timothy pollen allergen to be decomposed by trypsin. On the other hand, the ragweed pollen antigens $\mathrm{E}$ and $\mathrm{K}$ isolated by $\mathrm{King}$ et al. [6, 7] were refractory to trypsin, chymotrypsin and papain, but were readily degraded with pepsin and the bacterial protease nagarse. Rimington et al. [8] were unable to detect significant losses in skinreactivity of their "standard crude house dust allergen" submitted to treatment with trypsin for $24 \mathrm{hr}$. This finding was substantiated by Berrens [9], who demonstrated chemical stability of the purified house dust allergen fraction $\mathrm{E}$ towards trypsin, chymotrypsin and pepsin; carboxypeptidase released some C-terminal amino acids in low yield. Morris, Berrens and Young [10] subsequently reported the enzyme pronase to cleave 66 per cent of the peptide portion of the same allergen fraction, though skinreactivity remained virtually unaffected. The allergens in ipecacuanha were all found to be decomposed by trypsin and pepsin [11]; the tomato allergen fraction $\mathrm{G}$ proved chemically resistant towards trypsin and chymotrypsin, but not to pepsin [12]. The $\beta$-lactoglobulin-derived allergen from cow's milk was reported susceptible to trypsin and chymotrypsin [13]. No data are available on the influence of these enzymes upon the skin-reactive potency of these ipecac, tomato and milk allergen preparations.

The action of trypsin upon atopic allergens has recently become a particularly intriguing object for study because many purified atopic allergens have been demonstrated to incorporate 1-deoxy-2-ketoses (and the relevant tautomeric forms and sugar degradation products) attached in position 1 to the $\epsilon$-amino groups of lysine residues in the peptide moieties. Since trypsin is known to cleave peptide chains at the carboxyl end of lysyl- or arginyl-residues in proteins, it was considered that the allergens might perhaps be refractory to trypsin because of steric hindrance by the sugar residue conjugated to lysyl side-chains in the molecular framework of allergens. In consequence, a systematic and comparative study was undertaken of the susceptibility of a variety of atopic allergens to chemical decomposition by the enzymes trypsin, $\alpha$-chymotrypsin and pancreatic kallikrein. As an extension, the influence was studied of various atopic allergens upon the hydrolysis of normal protein and of synthetic ester substrates by these enzymes.

\section{MATERIALS}

Three enzyme preparations were employed, viz: $3 \times$ cryst. bovine trypsin (E.C. 3.4.4.4), spec. act. 10,000 BAEE units/mg*, bovine a-chymotrypsin (E.C. 3.4.4.5), spec. act. 12,300 ATEE units/mg, less than 20 BAEE units/mg according to the speci-

* In this paper the following abbreviations will be used. BAEE: $a-N$-benzoyl-L-arginine ethylester; ATEE : $N$-acetyl-L-tyrosine ethylester; TAME: $p$-toluenesulfonyl-L-arginine methyl ester; SBTI: soybean trypsin inhibitor; EACA: $\epsilon$-aminocaproic acid; EACAF: $N$ (1-deoxy-1D-fructosyl)-6-aminocaproic acid; ALAF: $N$ (1-deoxy-1-D-fructosyl)-L-alanine; OV: cryst. ovalbumin; OVA, OVR, OVE: reaction products of ovalbumin with L-arabinose, D-ribose and D-erythrose respectively; BLG: cryst. bovine $\beta$-lactoglobulin; BLGR: $\beta$-lactoglobulinribulose conjugate; BSA: cryst. bovine serum albumin; BSA-S: partially denatured BSA (substrate for proteolysis experiments); BSAR: $N$ (1-deoxy-1-D-ribulosyl) bovine serum albumin. Codes for allergens and fractions of allergenic extracts are explained in the text and have been compiled for easy review in Table 1 . 
fications of the manufacturer (Seravac Laboratories), and kallikrein (E.C. 3.4.4.2I, ex hog pancreas, Padutin (B) Bayer), spec. act. $1 \mathrm{KE} / \mathrm{mg}^{*}$ ). Synthetic ester substrates were BAEE (Sigma Chem. Corp.), ATEE and TAME (Koch-Light); the enzyme inhibitors employed were SBTI (chromatographic component VI, Mann Res. Labs), ovomucoid (egg white trypsin inhibitor type II-O, Sigma Chem. Corp.) and the kallikrein inhibitor from bovine lung (Trasylol $\left(\right.$ B Bayer, $5000 \mathrm{KIE} / \mathrm{ml}^{*}$ ), which is identical to Kunitz and Northrop's basic pancreatic trypsin inhibitor [14]. Other modifiers included DL-cycloserine (DL-4-amino-3-isoxazolidinone, Aldrich Chemicals), EAGA and the low molecular weight model conjugates EACAF and ALAF, which were synthesized as described elsewhere [17].

Protein-sugar model compounds incorporating synthetically introduced 1-amino1-deoxy-2-ketoses were prepared as reported before $[18,19]$ from crystalline proteins and chromatographically homogeneous aldoses. The model compound 1-(N)-deoxyribulose bovine serum albumin (BSAR) was prepared from the crystalline parent protein by keeping a 0.05 per cent solution at $50^{\circ}$ for $24 \mathrm{hr}$ in phosphate buffer, $\mathrm{pH}$ $7 \cdot 0,0 \cdot 01 \mathrm{M}$, containing 1 per cent $\mathrm{D}$-ribose, followed by extensive dialysis and lyophilization. Ovalbumin-arabinose (OVA), -ribose (OVR) and -erythrose (OVE) conjugates were obtained in a similar fashion after $24 \mathrm{hr}$ of reaction of the relevant aldoses with crystalline ovalbumin. The same procedure was applied for the preparation of the $\beta$-lactoglobulin-ribose complex (BLGR). The crystalline proteins were obtained commercially.

Purified kapok allergens KP-C, KP-D and KP-E were isolated as before [20]. Allergens from Radix ipecacuanhae included the fractions IPC-D, IPC-F and IPC-H (compare ref. 21); the two last fractions were prepared from the first by isoelectric precipitation (I.E.P. of fraction IPG-F at $\mathrm{pH} 5 \cdot 5-6 \cdot 0$; fraction IPC-H not precipitable in the pH-range $2 \cdot 5-7 \cdot 0$ ). The direct extract FE-A and the dialyzed extract FE-B from aged feathers were used as a source of feather allergens [22]. Several fractions from house dust extracts were applied, viz : HE-B (precipitated with ammonium sulphate at 0.35 sat. from a benzoic acid adsorbed, acetone-precipitated and dialyzed house dust extract as described in detail before [23, 24]. Fractions HE-D (precipitated at $\mathrm{pH} 3 \cdot 1$ from a dialyzed solution of the precipitate at $0 \cdot 35-0 \cdot 85$ ammonium sulphate sat.) and HE-E (supernatant at $\mathrm{pH} 3 \cdot 1$ ) were also employed, the latter being the most active allergen fraction isolated from house dust thus far $[23,24]$. Fractions from human dandruff were isolated as previously reported and involved HD-B (precipitated from a dialyzed extract with ammonium sulphate at 0.35 saturation), HD-D (precipitated at $\mathrm{pH} 4.2$ from a dialyzed solution of the 0.35 0.85 ammonium sulphate precipitate) and HD-E (supernatant at $\mathrm{pH} 4.2$ ), the latter being the fraction possessing the highest specific activity in skin tests [25]. The skinreactive tomato allergen, fraction TO-G, was isolated as recently described [12]. The pyrethrum allergens consisted of an unfractionated dialyzed extract of the commercial plant powder. Rye pollens (Lolium perenne, Sharp and Sharp, U.S.A.) were extracted with ammonium bicarbonate according to Johnson and Marsh [26], dialyzed and dried by lyophilization to give the direct extract GP-6; a more purified allergen fraction was isolated from a dialyzed extract of timothy pollen (Dactylis glomerata) by

\footnotetext{
* For definitions of kallikrein units (KE) and kallikrein inhibitor units (KIE) compare Werle et al. [15, 16]; $1 \mathrm{KE}$ of the available sample was found to be associated with $0 \cdot 1 \mathrm{mg}$ of dry material, while $1 \mathrm{KIE}$ of Trasylol is associated with $0.14 \mu \mathrm{g}$ of pure crystalline material.
} 


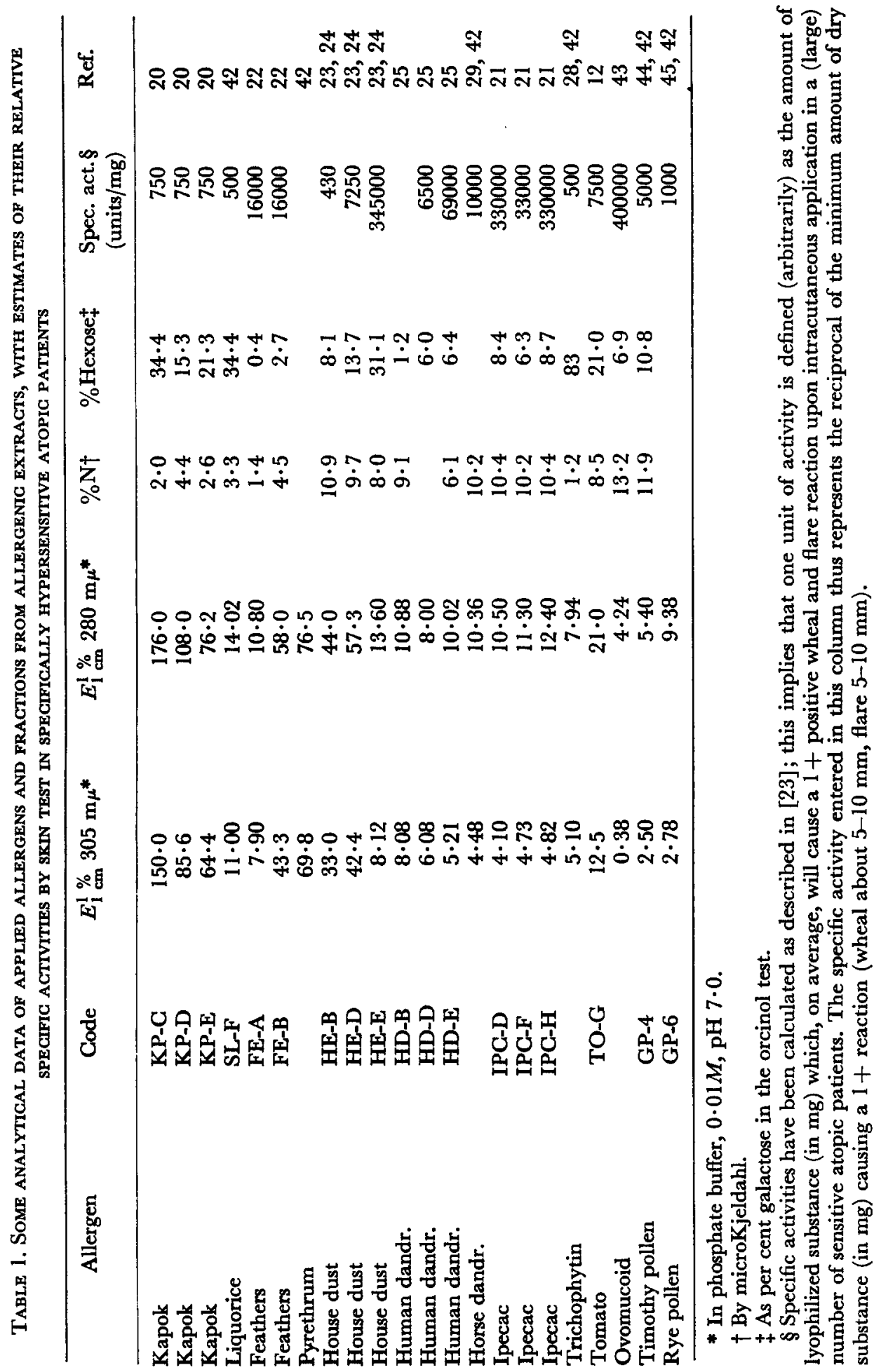


precipitation with ammonium sulphate at $0.35-0.85$ sat. as applied before [27]; code: GP-4. The galactomannan glycopeptide allergen trichophytin was isolated from Trichophyton mentagrophytes [28] and was supplied by Dr. J. H. Morris. A sample of dialyzed horse dandruff protein [29] was kindly donated by Dr. D. R. Stanworth.

Some pertinent analytical data of these allergens have been assembled in Table 1, together with estimates of their specific activities as determined by direct skin tests in hypersensitive atopic individuals.

\section{a. General}

\section{METHODS}

Ultraviolet absorption spectra were observed in the Ultrascan Recording Spectrophotometer (Hilger Watts) or in the Zeiss PMQII Spectrophotometer, using $1 \mathrm{~cm}$ quartz cells; solutions for absorption spectra were in $0.01 M$ phosphate buffer, $\mathrm{pH}$ $7 \cdot 0$, unless otherwise stated.

"Available" lysine was determined in allergens and model compounds by a micromodification of the method of Carpenter [30]. For this determination $5 \mathrm{mg}$ samples, in $0.5 \mathrm{ml} 10$ per cent sodium bicarbonate, were made to react with fluorodinitrobenzene $\left(0.5 \mathrm{ml} 3\right.$ per cent solution) for $4 \mathrm{hr}$ at $40^{\circ}$; excess reagent was then removed by ether extraction, and the recovered samples were hydrolyzed for $16 \mathrm{hr}$ with $6 \mathrm{~N} \mathrm{HCl}$ at $100^{\circ}$. After extraction of ether-soluble a-dinitrophenyl amino acids, the $\epsilon$-dinitrophenyl-lysine in the hydrolysate was determined colorimetrically at $435 \mathrm{~m} \mu$. Values are corrected for background absorption at $435 \mathrm{~m} \mu$ and the results have been expressed as per cent (by weight) of lysine amino acid in the sample having free 6 -amino groups available to react with fluorodinitrobenzene.

\section{b. Proteolysis}

The proteolysis of allergens was followed by $\mathrm{pH}$-stat measurement at $\mathrm{pH} \mathbf{8} \cdot \mathbf{0}$. The equipment comprised a Radiometer TTT1 automatic titrator, connected to the Radiometer recording Titrigraph SBR2/SBU1 and to the titration assembly TTA31 mounted with a syringe burette type SBU1 (Radiometer, Copenhagen). The all-glass syringe burette (capacity $0.5 \mathrm{ml}$ ) was connected to a reservoir containing $0.01 \mathrm{~N}$ $\mathrm{NaOH}$. The burette tip was attached to a teflon delivery tube inserted into the jacketed micro-titration vessel type V516 (capacity $0.5-5 \mathrm{ml}$ ), which held a micro glass electrode and a reference micro calomel electrode. The driving mechanism of the syringe burette was connected to the recorder by means of a flexible shaft; the burette delivered $20 \mu \mathrm{l}$ of $0.01 \mathrm{~N} \mathrm{NaOH}$ for each revolution. The solution in the titration vessel was kept at $37^{\circ}$ by circulating water from a thermostat bath; during titrations magnetic stirring provided for constant mixing. A steady stream of nitrogen, carbon dioxide and oxygen free, was led over the surface of the reaction mixture.

For inhibition studies with allergens the digestion of a standard protein substrate by the proteases in the presence or absence of allergens was likewise observed by $\mathrm{pH}$-stat measurement. The standard protein substrate in these experiments consisted of BSA, pretreated for $4 \mathrm{hr}$ at room temperature with $7 M$ urea, followed by extensive dialysis against 1 per cent $\mathrm{NaCl}$; the solution was made up with 1 per cent $\mathrm{NaCl}$ to give $2 \cdot 5$ $\mathrm{mg} / \mathrm{ml}$ of the protein substrate BSA-S. Since the preparation tended to become better digestible on aging (at $4^{\circ}$ ), a standard curve was run every $3 \mathrm{hr}$. Digestion curves were graphically extrapolated to zero time for establishing the initial velocity $v$. 


\section{c. Esterolysis}

The hydrolysis of BAEE by trypsin was followed by the method of Schwert and Takanake [31, 15], which measures the rate of increase of optical density during the enzymatic liberation of free benzoylarginine. The assay mixture in a cuvette consisted of $3 \mathrm{ml} \mathrm{BAEE}\left(10^{-3} \mathrm{M}\right)$ in tris-HCl buffer $(0.05 \mathrm{M}, \mathrm{pH} 8 \cdot 0$, the buffer being $0.02 \mathrm{M}$ with respect to calcium chloride), and $0.1 \mathrm{ml}$ of buffer containing variable quantities of allergen or modifier; trypsin $\left(20 \mu \mathrm{g}\right.$ in $\left.10^{-3} \mathrm{M} \mathrm{HCl}\right)$ was added at zero time. The course of the reaction was followed over a period of $3 \mathrm{~min}$, and calculations are for the first min of hydrolysis, i.e. in the linear portion of the curve (zero order kinetics). With TAME as the substrate (in tris-HCl buffer $0.1 M, \mathrm{pH} 7 \cdot 8$ ), the increase of extinction was followed at $246 \mathrm{~m} \mu$ for $120 \mathrm{sec}$ according to the procedure of Habermann and Klett [32], using $10 \mu \mathrm{g}$ of trypsin for each test. The esterase activity of $\alpha$-chymotrypsin was determined by observing the rate of decrease of optical density at $234 \mathrm{~m} \mu$ of the enzyme substrate ATEE $\left(2 \times 10^{-3} M\right.$ in tris-HCl buffer $0.05 M, \mathrm{pH} 7 \cdot 0$, the buffer containing $0.02 \mathrm{M}$ of calcium chloride) against $N$-acetyl-L-tyrosine for reference [15, 31], applying $10 \mu \mathrm{g}$ of enzyme per test and variable amounts of allergen or modifier (in $0.1 \mathrm{ml}$ ). Kallikrein was assayed spectrophotometrically with BAEE as the substrate according to Trautschold and Werle [15,33], the lyophilized enzyme sample being dissolved in dist. water to give $1 \mathrm{KE}$ per $\mathrm{ml}$ and per test. The BAEE concentration was $3 \times 10^{-3} \mathrm{M}$, no calcium ion added, and the increase of extinction at $253 \mathrm{~m} \mu$ was recorded over a period of $6 \mathrm{~min}$; further experimental details identical to those for trypsin.

Experiments with trypsin were performed at room temperature, with chymotrypsin and kallikrein use was made of thermostatted cuvette holders at $25^{\circ}$. Readings in experiments with allergens or modifiers were always taken against blanks containing these substances in identical concentration.

\section{a. Digestion of allergens}

\section{RESULTS}

In the standard assay procedure the course of the digestion process was followed by automatic titration of the $\mathrm{H}^{+}$-ions liberated during the hydrolysis of peptide bonds and by recording $\mathrm{NaOH}$-consumption against time. The reaction mixture contained $5 \mathrm{mg}$ of allergen dissolved in $3 \cdot 3 \mathrm{ml}$ unbuffered 1 per cent $\mathrm{NaCl} \mathrm{pH} 8 \cdot 0$, the solution being made up shortly before the experiment. Calcium chloride was added in a quantity of $0.1 \mathrm{ml}(0.1 \mathrm{M}$ in $\mathrm{l}$ per cent $\mathrm{NaCl} \mathrm{pH} 8.0)$. The enzyme solution (100 $\mu \mathrm{g}$, or $2 \mathrm{KE}$, of enzyme in $0.1 \mathrm{ml}$ of the same solvent), freshly prepared every $3 \mathrm{hr}$, was added at zero time through the hole of the nitrogen inlet tube by means of a tuberculin syringe fitted with a long blunt needle. The enzyme/substrate ratio in the experiments with trypsin and chymotrypsin was $1: 50$. The progress of the enzymatic reaction was observed over a period of at least $30 \mathrm{~min}$; all calculations are for $25 \mathrm{~min}$ of enzyme action.

The introduction of the enzyme sample into the reaction vessel caused some disturbance of $\mathrm{pH}$-equilibrium in the first few minutes. In consequence, the error in the calculated number of peptide linkages split in $25 \mathrm{~min}$ is of the order of 1 bond; values of 1-2 bonds entered in Table 2 signify virtually complete resistance to enzymatic attack. In spite of these limitations short-term incubation was preferred for comparative studies because of negligible enzyme autodigestion. 
With most atopic allergens the initial rate of degradation rapidly slowed down, and the reaction came to a stop within $10 \mathrm{~min}$. Only in the case of the allergens or fractions with a rather pronounced protein nature, i.e, grass pollen, ipecac fraction $F$, and the B-fractions of house dust and human dandruff, did hydrolysis continue to occur after $30 \mathrm{~min}$; this has been indicated with a plus sign in Table 2. A few typical examples of digestion curves have been reproduced in Fig. 1 .

No enhancement of digestibility was observed after attempted denaturation of the allergens by pretreatment with $7 M$ urea for $4 \mathrm{hr}$, followed by prolonged dialysis and

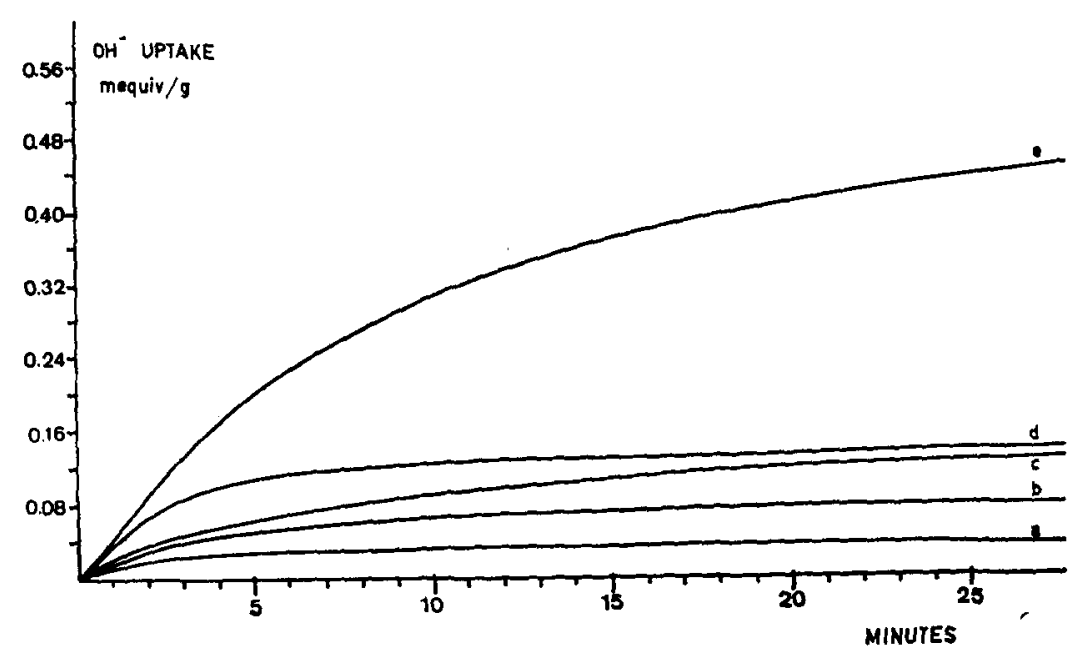

FIG. 1. Digestion curves of some atopic allergens or fractions of allergenic extracts $(5 \mathrm{mg})$ with trypsin $(100 \mu \mathrm{g})$ at $37^{\circ}$.

(a) House dust fraction HE-E, curve identical to that of human dandruff fraction HD-E.

(b) Ipecac fraction IPC-D.

(c) Total dialyzed horse dandruff protein, comprising about 50 per cent of active allergen.

(d) Ipecac fraction IPG-F.

(e) Rye grass pollen, total dialyzed extract, fraction GP-6. For allergens and codes see Table 1 .

recovery by lyophilization. This did not come as a surprise because the inhalant allergens from house dust, kapok, feathers, dandruff, etc. already present themselves as intrinsically denatured glycoproteins. However, denaturation with urea proved essential for measurable decomposition of the control protein BSA by all three proteases.

Results have been listed in Table 2 and have been expressed as the number of peptide bonds disrupted per $\mathrm{mol}$ in the first $25 \mathrm{~min} . *$ The molecular weight of all

* The results in Table 2 are given as fractional values for the calculated number of peptide bonds disrupted; this represents simply a relative scale of the mean number of linkages hydrolyzed under the conditions chosen.

Theoretically, results should have been expressed in the number of peptide bonds per mg of nitrogen, because the peptide contents of various allergens differ appreciably (Table 1). However, the required correction factors for individual allergens escape exact evaluation due to heavy losses of Kjeldahl-nitrogen in Maillard-type products [17] and reported for instance for kapok [20] and feather allergens [22]; this method of calculation would therefore have caused larger discrepancies than neglecting the carbohydrate contents as done here (compare Table 1). 


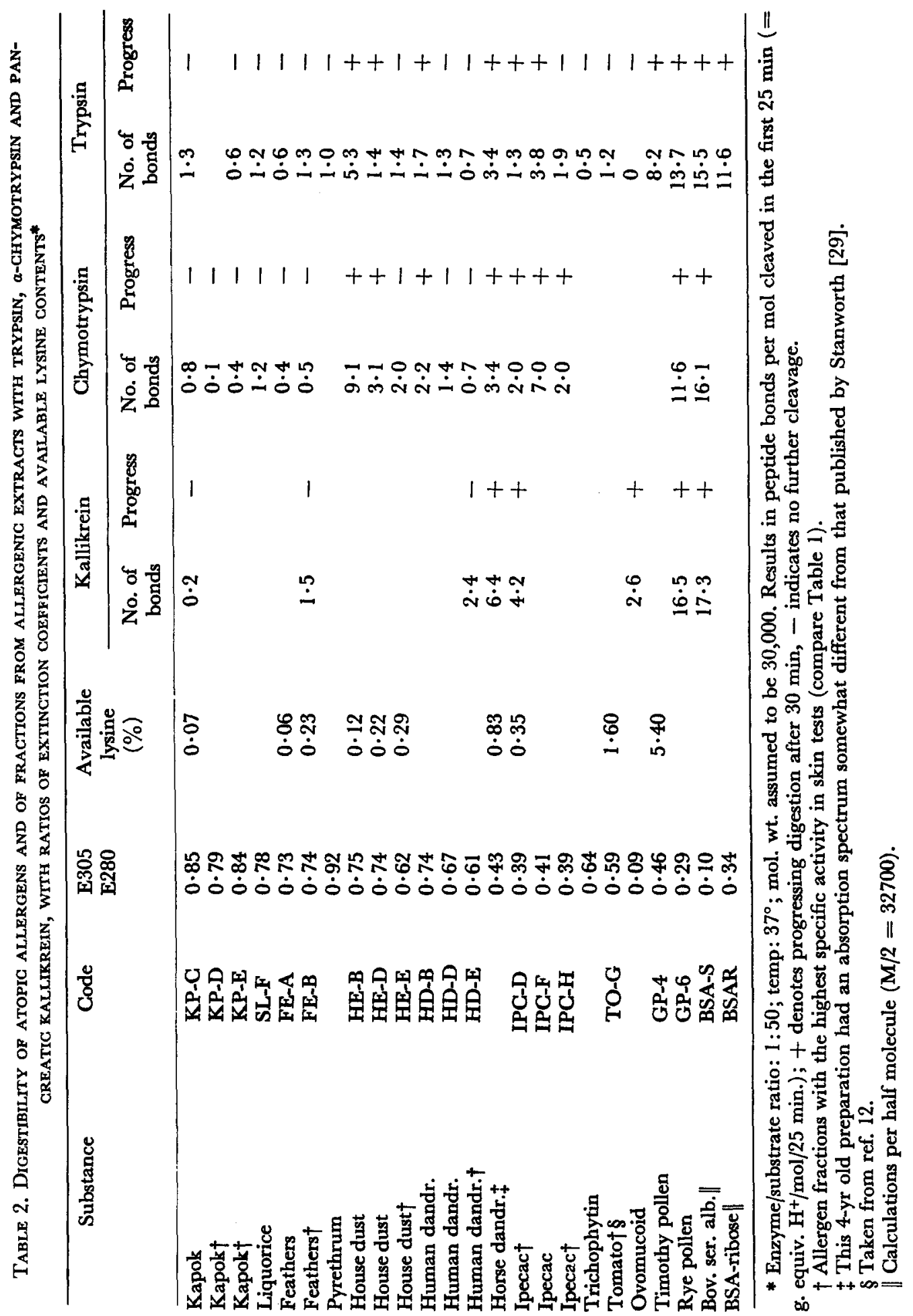


allergens was assumed to be 30,000 , which seemed a reasonable average of the published values or was indicated by the sedimentation coefficients $\left(S_{20}=2-3.5\right.$ for most allergens). Also included in Table 2 are the ratios of the extinction coefficients in the ultraviolet E305/E280, and the percentages of available lysine (see Methods, section a.). The absorption maximum at $305 \mathrm{~m} \mu$ of allergens and model compounds has been attributed to the 1-2-enol form of the $\left(N^{z}\right)$-1-amino-1-deoxy-2-ketose considered to be incorporated in the molecular framework of atopic allergens $[19,27,34]$. Since the peptide contents of diverse allergen preparations differ considerably (Table 1), the ratio E305/E280 is a more accurate spectroscopic approximation of the number of lysyl-sugar determinants than the absolute value of the extinction coefficient at 305 $\mathrm{m} \mu$.* A plot of substrate hydrolysis vs. E305/E280 ratios as shown in Figs. 2 and 3, incorporating the data taken from Table 2, reveals that the susceptibility of allergens to digestion by trypsin and chymotrypsin appears to be a function of the number of blocked lysine residues in the peptide portions of the allergens: digestibility sharply decreases with an increasing number of blocked lysine residues.

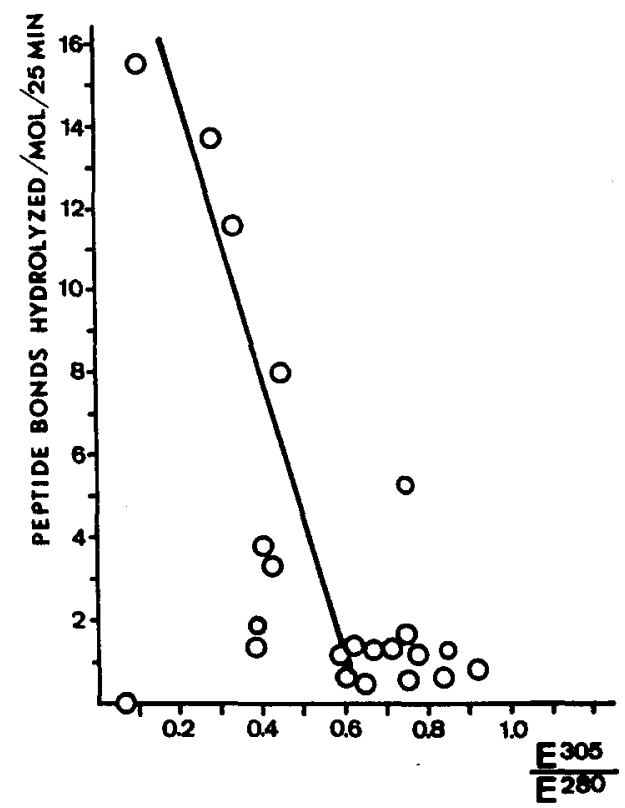

FIg. 2. Plot of digestibility in the first $25 \mathrm{~min}$ of various atopic allergens and other compounds with trypsin, vs. ratio of extinction coefficients of each separate substance in the ultraviolet at 305 and $280 \mathrm{~m} \mu$ as indicative of the degree of browning. Data taken from Table 2.

* The ratio E305/E280 for the synthetic model compound $N(1$-deoxy-1-D-fructosyl)-eaminocaproic acid was found to be 1.21 (ref. 17). This means that $280 \mathrm{~m} \mu$ absorption of the allergens includes a contribution (due to the descending leg of the $305 \mathrm{~m} \mu$ peak) by incorporated lysyl-sugar residues. The corrected value for $280 \mathrm{~m} \mu$ absorption of E280- $(0.82 \times \mathrm{E305})$ would therefore have been preferred for the above calculations of E305/E280 ratios, but since the situation is complicated by additional chromophores in the highly pigmented allergens [27], contributing in their turn to a nonspecific rise of $305 \mathrm{~m} \mu$ absorption, no correction factors have been applied in the present work. 


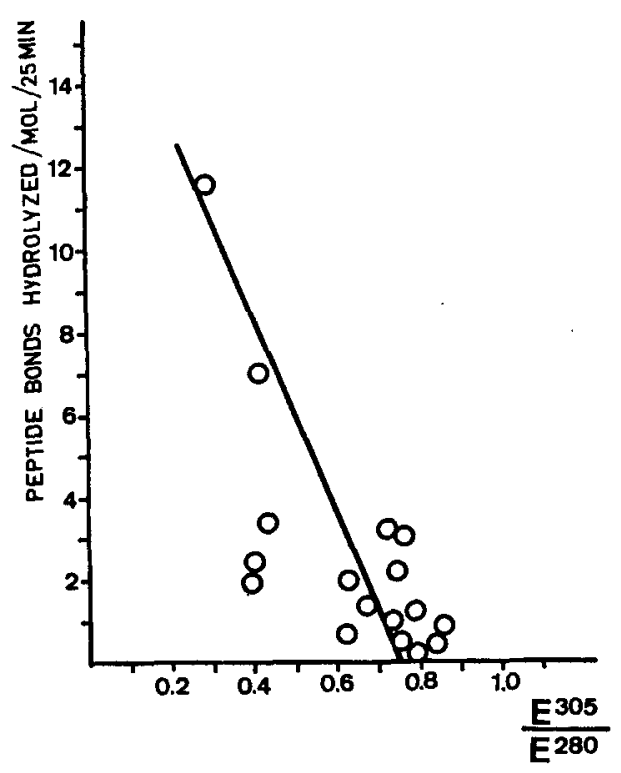

Fic. 3. Plot of digestibility in the first $25 \mathrm{~min}$ of various atopic allergens and other compounds with a-chymotrypsin, vs. ratio of extinction coefficients at 305 and $280 \mathrm{~m} \mu$ of each separate substance. Data taken from Table 2.

The inference of lysyl-sugar determinants being responsible for the diminished susceptibility of allergens to enzyme attack finds support in the observed difference between the degradation of BSA on the one hand and of its conjugate with D-ribose (BSAR) on the other (Table 2). It is further sustained by earlier results on synthetic model compounds, i.e. a series of $\beta$-lactoglobulin-lactose conjugates possessing skinreactivity in milk-sensitive atopic individuals described elsewhere [13]. Some pertinent characteristics of these conjugates have been summarized in Table 3 ; it follows from these data that there is an inverse relationship between the number of blocked lysine epsilon amino groups in the conjugates and the extent of digestion by trypsin. In Fig. 4 the contents of 'available' lysine have been plotted against the number of peptide linkages disrupted in the first hour of enzyme action. For the purpose of comparison, the relevant data for some allergens (Table 2) have been incorporated in the same graph, disregarding the shorter period of enzyme action (extension of the digestion period up to I hr would not have significantly altered the results with atopic allergens). Naturally, the total lysine contents of separate allergens are dissimilar; the susceptibility to degradation should therefore advantageously be plotted against the ratio of blocked lysine to total lysine in the samples as a more accurate parameter. Unfortunately, total and available lysines are known of only a limited number of allergens, precluding a more precise general evaluation.

A plot of the spectroscopic data of the above conjugates (Table 3) vs. peptide bond hydrolysis under the action of trypsin demonstrates that a similar relationship as shown in Fig. 1 exists between degradation by trypsin and the extinction coefficient at $305 \mathrm{~m} \mu$ as indicative of the proportion of $\left(N^{e}\right)$-1-amino-1-deoxy-2-ketoses (Fig. 5).

Table 3 also reveals that the percentage of available lysine in these model compounds is, of course, inversely proportional to the extinction coefficient at $305 \mathrm{~m} \mu$ 
Interaction of Enzymes and Allergens

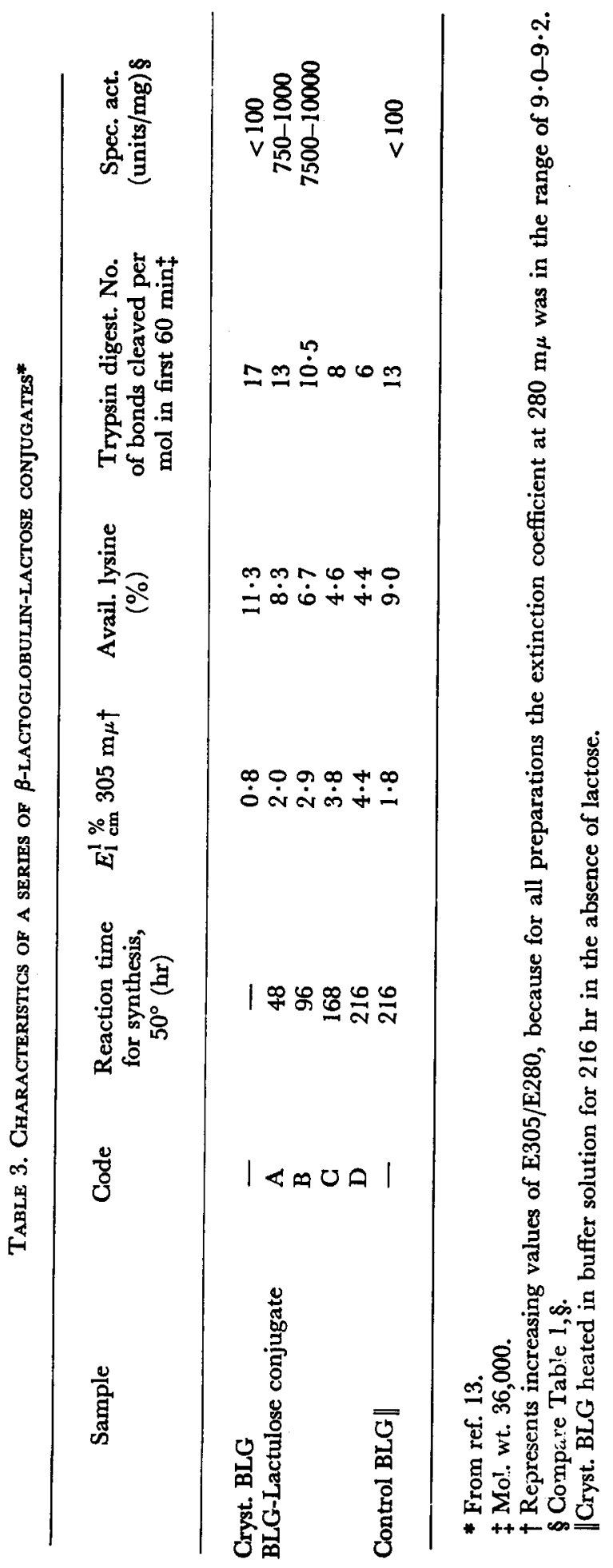




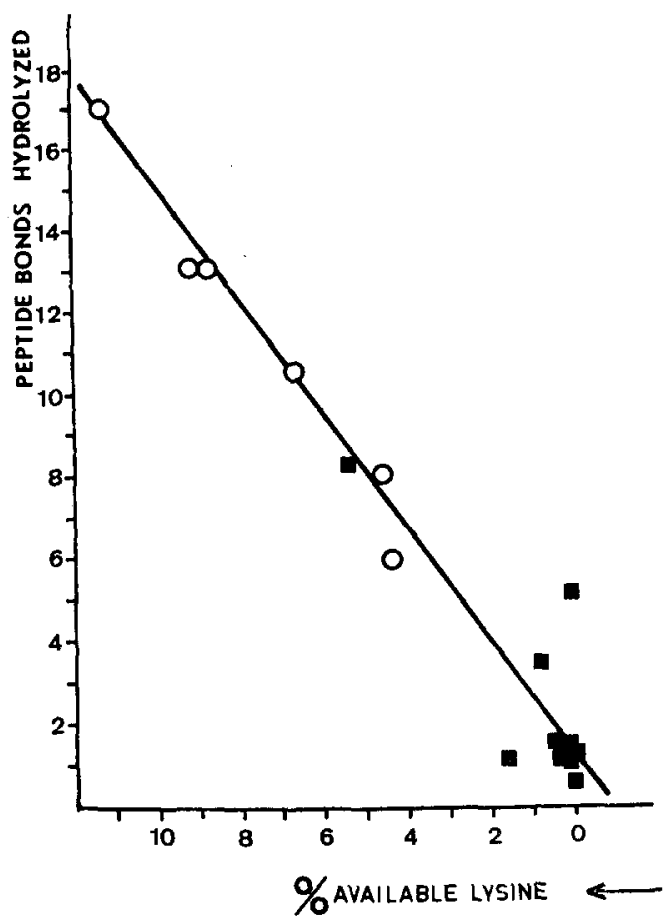

Fig. 4. Plot of percentage available lysine (Methods a.) of some atopic allergens (closed squares; Table 2) and model compounds (open circles, $\beta$-lactoglobulinlactose conjugates; Table 3 ) vs. digestibility with cryst. trypsin ( $25 \mathrm{~min}$ incubation period for allergens, $60 \mathrm{~min}$ for the model compounds). Data taken from

Tables 2 and 3.

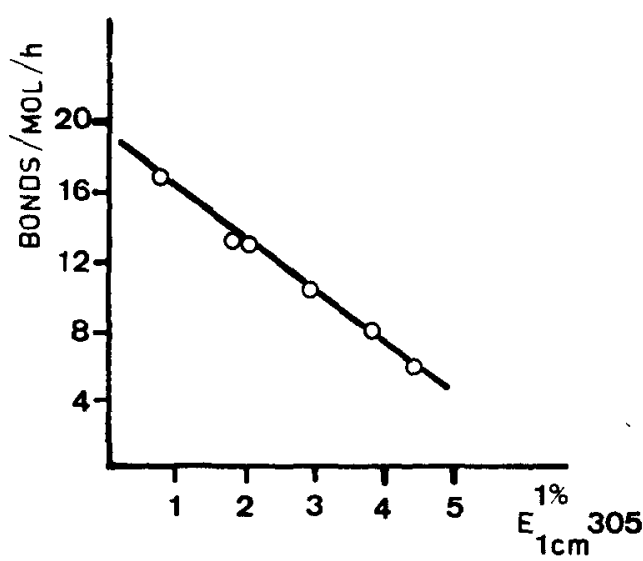

Fig. 5. Relationship of trypsin digestibility of $\beta$-lactoglobulin-lactose conjugates (per mol, in the first $60 \mathrm{~min}$ ) and the extinction coefficients at $305 \mathrm{~m} \mu$. Data taken from Table 3. 
and this observation justifies the employment in Figs. 2 and 3 of the E305/E280 ratios of allergens as a rough estimate of the number of blocked lysines per molecule.

The results of enzyme digestion listed in Table 2 show that atopic allergens are more resistant to trypsin than to chymotrypsin or pancreatic kallikrein, though the extent of decomposition by neither of the latter two enzymes is very spectacular. While refractoriness towards trypsin may be comprehended on the basis of the well known specificity of that enzyme, the resistance towards the other enzymes is less accessible to interpretation. In view of the peculiar shape of the trypsin digestion curves of most allergens (Fig. 1), showing a complete termination of enzyme activity after an initial short period of reaction, it was considered that the lysyl-sugar residues in the allergen structures might perhaps interact chemically with (the active site of) the proteases. With this in mind, the inhibiting action of allergens upon the proteolytic and esterolytic activity of the three enzymes was investigated next.

\section{b. Inhibition of the proteolytic activity of trypsin and chymotrypsin by atopic allergens}

The influence of allergens upon the hydrolysis of proteins was studied with BSA-S as the standard protein substrate, using the $\mathrm{pH}$-stat technique (Methods b.) Conditions of the experiments: $4 \mathrm{ml}$ of BSA-S substrate (10 $\mathrm{mg}$ of protein) were mixed with different quantities (up to $2 \mathrm{mg}$ ) of allergen or modifier in $0.4 \mathrm{ml} 1$ per cent $\mathrm{NaCl}$ $\mathrm{pH} 8 \cdot 0$. The enzyme solution $(0.1 \mathrm{ml})$ was added at zero time. Because of the negligible decomposition of most allergens under these conditions (Results a.), corrections for contribution to the digestion curves by allergen hydrolysis were applied only in the case of grass pollen (GP-4 and GP-6), crystalline BSA, and BSAR as the modifiers.

The process of hydrolysis of BSA-S by trypsin and a-chymotrypsin, but not by kallikrein, proved to be sensitive to the presence of allergens in the reaction system. The interference with the action of trypsin represented the most complex pattern and was studied in greater detail. As an example, Fig. 6 demonstrates the inhibiting action of the kapok allergen KP-E upon the hydrolysis of BSA-S by trypsin; all atopic allergens investigated behaved in a similar fashion, though they differed in their inhibiting capacities.

One outstanding feature of the influence of allergens upon protein hydrolysis by trypsin or chymotrypsin proved to be the decrease of the initial reaction velocity caused by the allergens (see Fig. 6). This is in contrast with the pattern of inhibition displayed by the familiar inhibitors ovomucoid (Fig. 7), SBTI and Trasylol, which inhibited trypsin and chymotrypsin non-competitively. Shortage of redundant supplies of purified allergens permitted a more detailed evaluation of the inhibitory mechanism for some allergens only. As an example, Table 4 lists the kinetic parameters* observed during BSA-S hydrolysis by trypsin in the presence and absence of a constant quantity of kapok allergen KP-C. From these data the Michaelis constant $K_{m}$ for BSA-S proteolysis, and the inhibitor constant $K_{i}$ (computed by known methods [35] from $K_{p}$, the effective Michaelis constant at this inhibitor concentration) were established by means of the Lineweaver-Burk plot given in Fig. 8, assuming the kinetics to fit a purely competitive mechanism of inhibition. Similarly, the apparent inhibitor constants $K_{\imath}$ were determined of a number of atopic allergens inhibiting trypsin, and these have been listed in Table 5 .

* Symbols of enzyme kinetics in conformity with Dixon and Webb [35]. 


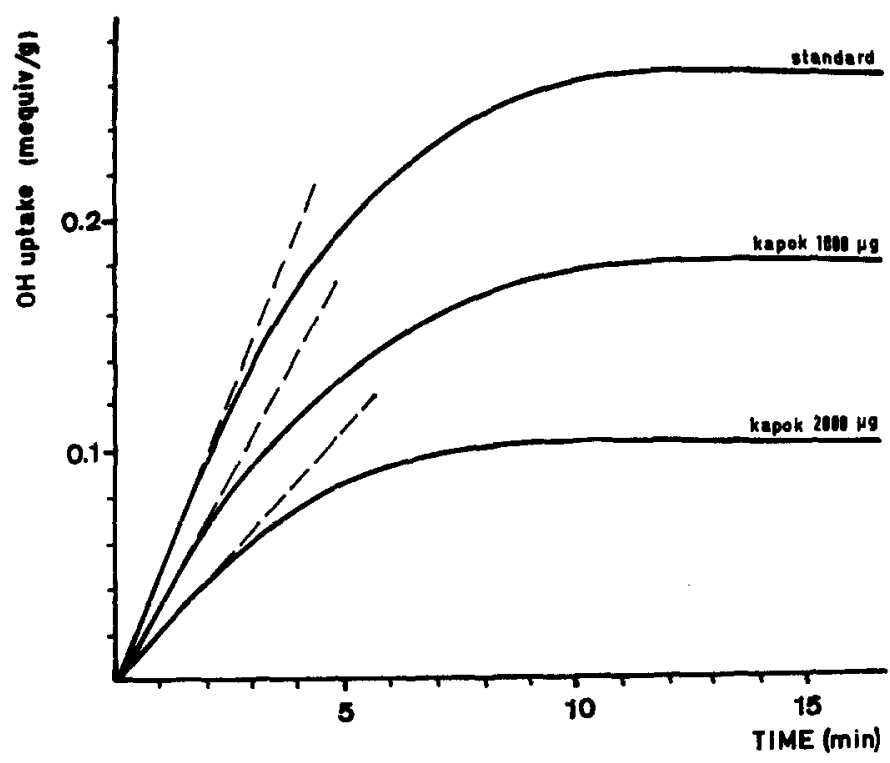

FIG. 6. Digestion curves of standard protein substrate (denatured bovine serum albumin, BSA-S, $10 \mathrm{mg}$ ) with trypsin $(200 \mu \mathrm{g})$ in the absence ('standard') and presence of kapok allergen fraction KP-E (1 mg and $2 \mathrm{mg}$ respectively).

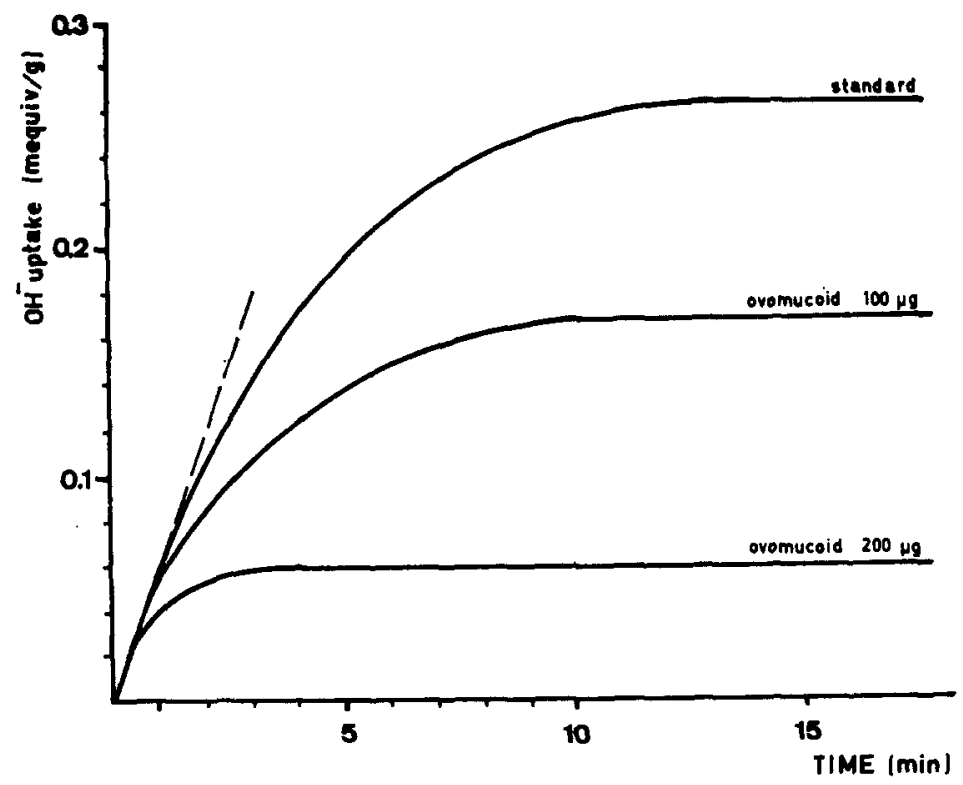

Fic. 7. Digestion curves of standard protein substrate (BSA-S, $10 \mathrm{mg}$ ) in the absence ('standard') and presence of ovomucoid (hen's eggs), 0.1 and $0.2 \mathrm{mg}$ respectively. Enzyme: trypsin $(200 \mu \mathrm{g})$. 
TABle 4. KINETIC PARAMETERS OF BSA-S hYDROLYSIS BY TRYPSIN (200 $\mu \mathrm{g})$ IN THE PRESENCE AND ABSENCE OF KAPOK ALLERGEN KP-C (2 mg)*

\begin{tabular}{|c|c|c|c|c|c|}
\hline $\begin{array}{l}\text { Substrate conc. } \\
\quad(s)(\mathrm{mg})\end{array}$ & $\begin{array}{c}1 / s \\
\left(\mathrm{mg}^{-1}\right)\end{array}$ & $\begin{array}{r}10^{-4} \cdot v_{s} \\
\text { (m-equiv. } \\
\text { min }^{-1} \text { ) }\end{array}$ & $\begin{array}{c}104 / v_{\star} \\
\text { (m-equiv. } \\
\text { min) }\end{array}$ & $\begin{array}{c}10^{-4} \cdot v_{l} \\
\text { (m-equiv. } \\
\min ^{-1} \text { ) }\end{array}$ & $\underset{\text { (m-equiv. }}{104 / v_{1}}$ \\
\hline 10 & $0 \cdot 100$ & $6 \cdot 0$ & $0 \cdot 16$ & $3 \cdot 8$ & 0.26 \\
\hline 8 & 0.125 & $5 \cdot 5$ & $0 \cdot 18$ & $2 \cdot 5$ & 0.40 \\
\hline 5 & $0 \cdot 200$ & $5 \cdot 0$ & 0.20 & $1 \cdot 9$ & 0.52 \\
\hline 2 & 0.500 & $3 \cdot 5$ & 0.28 & $1 \cdot 2$ & 0.86 \\
\hline
\end{tabular}

* $v_{\Perp}:$ initial velocity in the absence of kapok allergen; $v_{l}$ : initial reaction velocity in the presence of kapok allergen.

Michaelis constant $K_{m}=2.1(\mathrm{mg})$; Inhibitor constant $\mathrm{K}_{t}(\mathrm{KP}-\mathrm{G})=0.50$ (mg).

Table 5. Apparent inhibitor constants of some atopic allergens. Substrate: BSA-S; EnzyMe: TRYPSIN*

\begin{tabular}{llc}
\hline \multicolumn{1}{c}{ Allergen or modifier } & Code & $K_{t}(\mathrm{mg})$ \\
\hline Kapok & KP-C & $0 \cdot 50$ \\
Kapok & KP-E & $0 \cdot 40$ \\
Feathers & FE-B & $0 \cdot 40$ \\
House dust & HE-E & $0 \cdot 37$ \\
Human dandruff & HD-E & $0 \cdot 36$ \\
Timothy pollen & GP-4 & $0 \cdot 29$ \\
Rye pollen & GP-6 & $0 \cdot 25$ \\
BSA-ribose conjugate & BSAR & $1 \cdot 25$ \\
& & \\
\hline
\end{tabular}

For determination, and conditions of the experiments: see text.

As observed during the proteolysis of the allergens themselves (Results a.), it was found that the reaction velocity of BSA-hydrolysis in the presence of allergens dropped to zero after an initial period of $10-15 \mathrm{~min}$, indicating that the inhibitory action of the allergens upon trypsin is not exclusively of the competitive type, but includes an element of true enzyme inactivation. This complication does not directly manifest itself in the above calculations because these are based on initial velocities. The idea that the interference of allergens with trypsin action is not exclusively competitive gathered significance during experiments with the synthetic compound EACAF as a model of the structural determinant suspected in atopic allergens. Figure 9 reproduces the digestion curves of BSA-S by trypsin in the presence of different quantities of EACAF; these curves display the same phenomenon of apparent enzyme inactivation, in contrast with the curves recorded in the presence of EACA, a far less powerful inhibitor. Incorporation in a Lineweaver-type plot (Fig. 10) of the relevant kinetic parameters computed from these graphs, and evaluation of the inhibitor constants by a graphical method [35] (employing the value 1/V for BSA-S proteolysis established 



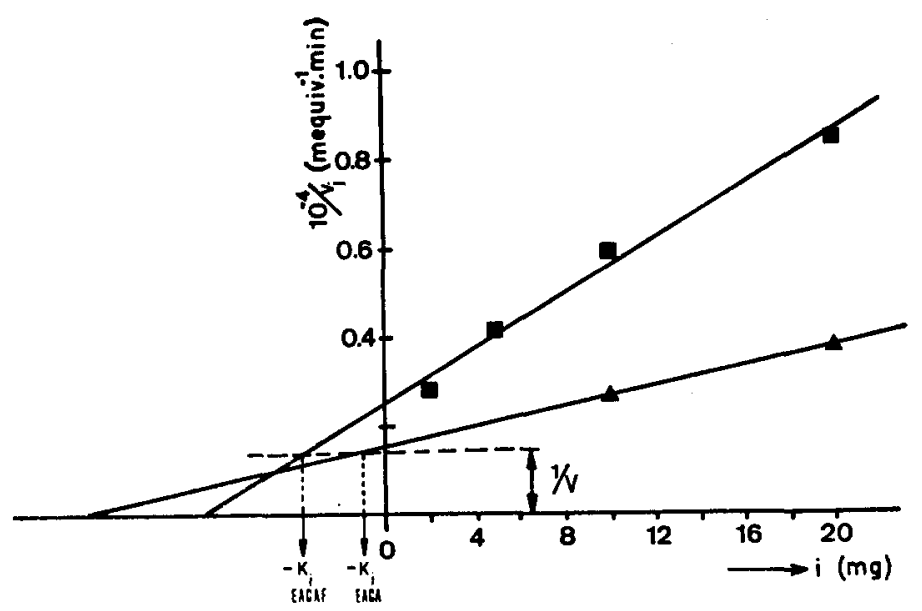

FIG. 10. Lineweaver-Burk plot of hydrolysis of BSA-S (10 mg) in the presence of different concentrations of EACA (triangles) and EACAF (squares), and evaluation of the inhibitor constants. Kinetic parameters computed from curves reproduced in Fig. 9.

separately) surprisingly gave a higher $K_{t}$-value for $\operatorname{EACAF}\left(K_{t}=3.5 \mathrm{mg}\right)$ than for EACA $\left(K_{t}=1.0 \mathrm{mg}\right)$, though the reverse was expected on the basis of the experimental results (Figs. 9 and 10). This indicates that this particular graphical method for the assessment of $K_{t}$-values, permissible in the case of a purely competitive type of inhibition only [35], leads to false values. Tentatively, the pattern of inhibition of trypsin by EACAF and by atopic allergens was therefore concluded to be of the mixed type, exhibiting competitive as well as non-competitive features.

No evidence was obtained for the partial inactivation of chymotrypsin by a mechanism of non-competitive inhibition; the allergens investigated (Table 5) inhibited chymotrypsin exclusively according to competitive kinetics, although the inhibiting capacity of individual allergens for this enzyme was less than for trypsin. Thus, for the inhibitor constant $K_{l}$ of the kapok allergen KP-C, interacting with the proteolytic action of chymotrypsin, a value of $1.9(\mathrm{mg})$ was found; for the feather allergen FE-B a $K_{i}$-value of $0.60(\mathrm{mg})$ was obtained. (Compare Table 5 for trypsin inhibition). Lack of adequate supplies of other allergens precluded more detailed experiments required for constructing sufficiently reliable plots to allow the calculation of further inhibitor constants.

In contrast with trypsin and chymotrypsin, the proteolytic activity of kallikrein proved to be unimpaired in the presence of any of the allergens investigated (feathers, human dandruff, ipecac, kapok, grass pollen); the enzyme was not inhibited by ovomucoid, except in excessive dosage, but SBTI and Trasylol powerfully suppressed its enzymatic activity.

c. Influence of atopic allergens upon the esterolytic activity of trypsin, a-chymotrypsin and pancreatic kallikrein

During extended series of experiments the interaction was studied of allergens with the above enzymes hydrolyzing synthetic ester substrates (Methods c.) None of the 
allergens investigated (Table 6) exerted a detectable effect upon the esterase activity of trypsin, chymotrypsin or kallikrein, nor did the model compounds or other modifiers significantly interfere with esterolysis. The highest level of allergen employed in these studies amounted to $400 \mu \mathrm{g}$ for $10 \mu \mathrm{g}$ of crystalline enzyme (or for $1 \mathrm{KE}$ of kallikrein). Estimating the mean mol. wt. of allergens at 30,000 , it follows that a molecular excess of $30: 1$ did not cause detectable inhibition of the esterase activity of trypsin and chymotrypsin, while the highest ratio with respect to the kallikrein sample $(M=30,000$, ref. 36) was about $4: 1$. In the case of the low mol. wt. compounds tested, the molecular ratio of modifier to enzyme even exceeded values of 2000:1. For the record, a compilation of the substances employed and a survey of the results is given in Table 6 .

A significant suppression of the esterase action of trypsin and chymotrypsin was observed with the potent inhibitors ovomucoid, SBTI and Trasylol; the esterolytic

Table 6. InfLuence of SOME ALlergens AND Other modifiErs (MAX. DOSE $400 \mu \mathrm{g}$ ) UPON THE ESTEROLYTIC ACTTVITY OF TRYPSIN $(10 \mu \mathrm{g})$, a-CHYMOTRYPSIN $(10 \mu \mathrm{g})$ AND PANCREATIC KALLIKREIN (1 KE)*

\begin{tabular}{|c|c|c|c|c|c|}
\hline \multicolumn{2}{|l|}{$\begin{array}{c}\text { Enzyme } \\
\text { Substrate }\end{array}$} & $\begin{array}{r}\mathrm{Tr} \\
\text { BAEE }\end{array}$ & psin & $\begin{array}{c}\text { a-Chymotrypsin } \\
\text { ATEE }\end{array}$ & $\begin{array}{l}\text { Kallikrein } \\
\text { BAEE }\end{array}$ \\
\hline Kapok allergen & KP-C & - & - & - & \\
\hline Kapok allergen & KP-D & - & - & & \\
\hline Kapok allergen & KP-E & - & - & - & - \\
\hline Liquorice & SL-F & & $40 \dagger$ & & \\
\hline Feathers & FE-B & & - & - & - \\
\hline House dust & HE-D & - & & - & \\
\hline House dust & HE-E & - & & - & - \\
\hline Human dandruff & HD-B & - & & - & \\
\hline Human dandruff & HD-E & - & - & - & - \\
\hline Horse dandruff & & - & - & & - \\
\hline Ipecac & IPG-D & - & - & - & - \\
\hline Ipecac & IPC-F & - & - & & \\
\hline Trichophytin & & - & & - & \\
\hline Timothy pollen & GP-4 & - & - & - & - \\
\hline Ovalbumin-ribose & OVR & - & - & - & \\
\hline -arabinose & OVA & - & - & & \\
\hline -erythrose & OVE & - & - & - & \\
\hline Cryst. BLG & BLG & - & - & & \\
\hline BLG-ribose conj. & BLGR & - & & - & \\
\hline Ovomucoid & & + & & - & - \\
\hline SBTI & SBTI & + & & + & - \\
\hline Trasylol & & + & & + & + \\
\hline DL-cycloserine & & $49 \dagger$ & $85 \dagger$ & & - \\
\hline Fructosyl-alanine & ALAF & - & & - & \\
\hline Fructosyl-EACA & EACAF & - & - & - & - \\
\hline 6-Aminocaproic acid & EACA & - & - & - & \\
\hline
\end{tabular}

* The minus sign indicates no inhibition, + denotes 90-100 per cent inhibition. For codes and abbreviations see footnote to page 856 and Materials section.

$\dagger$ Per cent inhibition. 
cleavage of BAEE by kallikrein was inhibited by Trasylol, but not by SBTI or ovomucoid. Some influence was noted of the liquorice allergen SL-F upon TAME-hydrolysis by trypsin (to an extent of $\mathbf{4 0}$ per cent inhibition in the weight ratio of $40: 1$ ), but in view of the extreme excess required for detectable effects no significance was attached to this observation. The inhibition of trypsin, but not of kallikrein, by DL-cycloserine perhaps merits some notice because the compound encompasses an isoxazolidine nucleus, which is an isomer of the pseudo-isoxazoline configuration proposed as one of the stabilized forms of the lysyl-sugar determinant [17]. However, the model compounds EACAF and ALAF were found not to inhibit esterolysis detectably (Table 6).

\section{DISGUSSION}

The results of this investigation indicate that there is a link between the observed resistance of most atopic allergens towards enzymatic digestion by trypsin, chymotrypsin or kallikrein, and the occurrence of lysyl-sugar structural determinants of the 1-amino-1-deoxy-2-ketose type in the molecular framework of the allergens. The difference observed between the totally undigestable allergens (house dust, feathers, kapok, pyrethrum, human dandruff etc.) and those hydrolyzed to some extent by the proteases (grass pollen, horse dandruff, proteinaceous fractions from house dust, ipecac and human dandruff) can in fact be traced to variations in the degree of binding of sugars to the $\epsilon$-amino functions of lysine residues in the corresponding allergens: there is a close direct correlation between susceptibility to enzyme attack and the content of available lysine, and an inverse correlation with the extent of aminodeoxyketose incorporation.

The intractability of most allergens with respect to attack by trypsin and chymotrypsin finds an explanation in the mechanism of inhibition of the proteolytic activity of these enzymes by atopic allergens. Both enzymes are known to possess structurally identical active sites, despite their distinct specificities [37]. It is likely that the successful competition of allergens with protein substrate molecules for the enzyme surface is due to a particular affinity of the lysyl-sugar determinant for the active site; this would satisfactorily explain the competitive inhibition of protein hydrolysis and the resistance of allergens towards degradation by trypsin and chymotrypsin. The additional element of enzyme inactivation in the case of trypsin, a protease selectively cleaving proteins at the carboxyl end of lysyl- or arginyl residues, suggests a more intimate contact with the active site of that enzyme and explains the higher degree of resistance of allergens towards trypsin. The observation that the allergens are less refractory towards kallikrein, and do not inhibit this enzyme, is in line with these assumptions because this protease is essentially different from the other enzymes, though its specificity is as yet ill-defined. The mechanism of interaction which brings about the inactivation of trypsin remains obscure, but the reducing power of the ( $\epsilon$-amino-lysyl)-1-deoxy-2-ketose and its enolic tautomers perhaps is an important factor. The recent discovery of the role of one particular lysine residue (lysine-15) of the basic pancreatic trypsin inhibitor in the process of trypsin inhibition [38] may provide an interesting collation for further studies.

The failure of allergens to inhibit the esterase activity of the three enzymes investigated need not be contradictory to the above considerations because the sites involved in proteolysis and esterolysis need not necessarily be identical; a similar situation is 
encountered with human $a_{2}$-macroglobulin, which inhibits the proteolytic action of trypsin, but leaves the esterase activity unimpaired [39].

Though, in general, the chemical fragmentation of allergens seems to be associated with loss of allergenic (skin-) activity, it does not necessarily follow that the integrity of tertiary structure is essential for allergenic activity, because the tertiary configuration must already have been altered (one obvious cause being loss of the contribution of several foci of positive charge by the conjugation of free amino groups to sugars); in the present work the pretreatment with urea did not enhance enzyme digestibility of the allergens. In this connection, it is remarkable that, for individual extracts, those fractions possessing the highest specific activity in skin tests seem to fall into the category of the most highly resistant protein or glycoprotein fractions (compare Tables 1 and 2, house dust fractions HE-E, HE-B and HE-D, ipecac fractions IPG-D and IPC-F). The more classical protein fractions of a particular extract, at once the more labile towards protease digestion, tend to exert a lower allergenic activity. The skinreactivity of the synthetic $\beta$-lactoglobulin-lactose conjugates (Table 3 ) rose almost in proportion to the increasing degree of sugar conjugation and the decreasing sensitivity towards trypsin [13]. This observation may have some curious consequences; according to Maurer [40], antigens must be at least partly degradable by enzymes for inducing antibody formation. Atopic allergens are normally considered very poor antigens in man, with the exception perhaps of grass pollen allergens, while the feather [22] and caddis fly allergens [41] fail to stimulate the elicitation of specific antibodies even in the rabbit. This antithesis might perhaps explain the uneasiness referred to in the introduction, because it concerns the vital question whether, in man, atopic allergens really exert their activity on the basis of their alleged antigenic properties.

Attempts to discover a relationship between enzyme digestibility (or any other physical parameter) and the specific activity of distinct separate allergens (Tables 1 and 2) would of course be a logical and fascinating consequence of these considerations. To do this would imply the proposal of one single mechanism of action for diverse atopic allergens on the basis of a common structural denominator; such a holistic approach to atopy requires more solid evidence than the present paper can give.

Acknowledgements-Thanks are due to Miss H. de Lange and Mr. M. A. T. Slotemaker de Bruine for technical assistance at various stages of this work. The generous gifts of Padutin and Trasylol by N. V. Nedigepha (Amsterdam, Holland) are gratefully acknowledged.

\section{REFERENCES}

1. Spizs J. R., Chambers D. C., Coulson E. J., Bernton H. S. and Stevens H., J. Allergy 24, 483 (1953).

2. Herbertson S., Porath J. and Colldahl H., Acta chem. scand. 12, 737 (1958).

3. Augustin R., Immunology 2, 230 (1959).

4. Johnson P. and MARsh D. G., Immunochemistry 3, 101 (1966).

5. Malley A. and Dobson R. L., Fedn Proc. Fedn Am. Socs exp. Biol. 25, 729 (1966).

6. King T. P. and Norman P. S., Biochemistry, N.Y. 1, 709 (1962).

7. King T. P., Norman P. S. and Liahtenstein L. M., Biochemistry, N.Y. 6, 1992 (1967).

8. Rumington C., Stillwell D. E. and Maunsell K., Br. J. exp. Path. 28, 309 (1947).

9. Berrens L., Clinica chim. acta 8, 457 (1963).

10. Morris J. H., Berrens L. and Young E., Clinica chim. acta 12, 407 (1965).

11. Berrens L. and Young E., Biochim. biophys. Acta 63, 559 (1962).

12. Bleumink E., Berrens L. and Young E., Int. Archs Allergy appl. Immun. 31, 25 (1967).

13. Bleuminx E. and Berrens L., Nature, Lond. 212, 541 (1966). 
14. Anderer F. A. and Hörnle S., Z. Naturf. 20 B, 462 (1965).

15. Bergmeyer Hans-Ulrich (Editor), Methoden der Enzymatischen Analyse. Verlag Chemie, Weinheim (1962).

16. Vogel R., Trautschold I. and Werle E., Natürliche Proteinasen-Inhibitoren. Monographie Biochemie u. Klinik, Georg Thieme Verlag, Stuttgart (1966).

17. Berrens L., Recl. Trav. chim. Pays-Bas 85, 1117 (1966).

18. Berrens L. and Bleumink E., Recl. Trav. chim. Pays-Bas 85, 59 (1966).

19. Berrens L. and Bleumink E., Int. Archs Allergy appl. Immun. 28, 150 (1965).

20. Berrens L., Int. Archs Allergy appl. Immun. 29, 575 (1966).

21. Berrens L. and Young E., Int. Archs Allergy appl. Immun. 22, 51 (1963).

22. Berrens L., Int. Archs Allergy appl. Immun. 34, 81 (1968).

23. Berrens L. and Young E., Int. Archs Allergy appl. Immun. 19, 341 (1961).

24. Berrens L., Morris J. H. and Versie R., Int. Archs Allergy appl. Immun. 27, 129 (1965).

25. Berrens L., Morris J. H. and Young E. Dermatologica 132, 433 (1966).

26. Johnson P. and Marsh D. G., Europ. Polym. J. 1, 63 (1965).

27. BERrens L., Immunochemistry 4, 37 (1967).

28. Barker S. A., Cruickshank C. N. D., Morris J. H. and Wood S. R., Immunology 5, 627 (1962).

29. Stanworth D. R., Biochem. J. 65, 582 (1957).

30. Carpenter K. J., Biochem. J. 77, 604 (1960).

31. Schwert G. W. and Takanake Y, Biochim. biophys. Acta 16, 570 (1955).

32. Habermann E. and Klett W., Biochem. Z. 346, 133 (1966).

33. Trautschold I. and Werle E., Hoppe Seyler's Z. physiol. Chem. 325, 48 (1961).

34. BERRENS L., Immunochemistry 4, 81 (1967).

35. Dixon M. and WeBb E. G., Enzymes, 2nd edn. Longmans, Green, London (1964).

36. Frtz H., Trautschold I. and WerLe E., Hoppe Seyler's Z. physiol. Chem. 342, 253 (1965)

37. Neurath H., Scient. Am. 211, 68 (1964).

38. Chauvet J. and Acher R., J. biol. Chem. 242, 4274 (1967).

39. James K., TAylor F. B. and Fudenberg H. H., Clinica chim. acta 13, 359 (1966).

40. Maurer P. H., Proc. Soc. exp. Biol. Med. 113, 553 (1963).

41. Langlois C., Shulman S. and Arbesman C. E., J. Allergy 34, 235 (1963).

42. BerRens L., unpublished material.

43. Bleumink E., Thesis Utrecht University 1967 (in Dutch).

44. Malley A., Lietze A. and Reed C. E., J. Allergy 31, 413 (1960).

45. Brtton C. J. C., Coombs R. R. A., Johnson P. and Thorne H. V., Int. Archs Allergy appl. Immun. 13, 305 (1958). 